\title{
Block of AIDS-Kaposi's Sarcoma (KS) Cell Growth, Angiogenesis, and Lesion Formation in Nude Mice by Antisense Oligonucleotide Targeting Basic Fibroblast Growth Factor
}

\section{A Novel Strategy for the Therapy of KS}

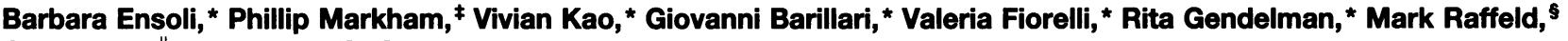 \\ Gerald Zon," and Robert C. Gallo* \\ * Laboratory of Tumor Cell Biology and ${ }^{\S}$ Laboratory of Pathology, National Cancer Institute, National Institutes of Health, Bethesda, \\ Maryland 20892; ${ }^{\ddagger}$ Advanced BioScience Laboratories, Inc., Kensington, Maryland 20895; and "Lynx Therapeutics Inc., Hayward, \\ California 94545
}

\begin{abstract}
Kaposi's sarcoma (KS) is the most frequent tumor of HIV1-infected individuals (AIDS-KS). Typical features of KS are proliferating spindle-shaped cells, considered to be the tumor cells of $\mathrm{KS}$, and endothelial cells forming blood vessels. Basic fibroblast growth factor (bFGF), a potent angiogenic factor, is highly expressed by $\mathrm{KS}$ spindle cells in vivo and after injection in nude mice it induces vascular lesions closely resembling early $\mathrm{KS}$ in humans. Similar lesions are induced by inoculating nude mice with cultured spindle cells from AIDS-KS lesions (AIDS-KS cells) which produce and release bFGF. Here we show that phosphorothioate antisense (AS) oligonucleotides directed against bFGF mRNA (ASbFGF) inhibit both the growth of AIDS-KS cells derived from different patients and the angiogenic activity associated with these cells, including the induction of KS-like lesions in nude mice. These effects are due to the block of the production of bFGF which is required by AIDS-KS cells to enter the cell cycle and which, after release, mediates angiogenesis. The effects of ASbFGF are specific, dose dependent, achieved at low (0.1-1 $\mu \mathrm{M})$, nontoxic, oligomer concentrations, and are reversed by the addition of bFGF to the cells, suggesting that ASbFGF oligomers are promising drug candidates for KS therapy. (J. Clin. Invest. 1994. 94:1736-1746.) Key words: endothelial cells • cell invasion - cell cycle
\end{abstract}

\section{Introduction}

Kaposi's sarcoma (KS) ${ }^{1}$ is an angioproliferative disease which in recent years has become epidemic in association with HIV1 infection (AIDS-KS) (1-4). Characteristic histological fea-

G. Barillari's present address is Department of Experimental Medicine, II University of Rome, Rome 00173, Italy.

Address correspondence to Dr. Barbara Ensoli, Laboratory of Tumor Cell Biology, National Cancer Institute, National Institutes of Health, Bldg. 37, Rm. 6A09, 9000 Rockville Pike, Bethesda, MD 20892.

Received for publication 28 March 1994 and in revised form 20 June 1994.

1. Abbreviations used in this paper: AS, antisense; CM, conditioned media; ECGF, endothelial cell growth factor; H-UVE, human umbilical vein-derived endothelial; KS, Kaposi's sarcoma.

The Journal of Clinical Investigation, Inc.

Volume 94, November 1994, 1736-1746 tures of KS include the proliferation of spindle-shaped cells (KS cells) of vascular origin considered to be the "tumor" cells of KS, and of normal endothelial cells forming blood vessels (angiogenesis), inflammatory cell infiltration, and edema (1-5). Previous observations suggested that, at least in early stages, $\mathrm{KS}$ is not a real tumor but a cytokine-mediated hyperplastic/proliferative disease with angiogenic factors playing a key role in its development (6-9). For example, supernatants from spindle cells derived from KS lesions of AIDS patients (AIDS-KS cells) (6-8) demonstrate angiogenic properties. Specifically, they induce normal endothelial cells to migrate, degrade, and cross the basement membrane (invasion), and to proliferate $(8,10)$; the events required for angiogenesis (11). When AIDS-KS cells are placed into the chorioallantoic membrane of 9-day-old fertilized chick eggs they induce the formation of blood vessels, and when injected into nude mice they induce vascular lesions closely resembling early $\mathrm{KS}$ in humans (7). These KS-like lesions are of mouse cell origin, regress when the proliferation of AIDS-KS cells terminates, and are not elicited by fixed cells (7). Similar effects are obtained by inoculation of AIDS-KS cell derived supernatants (12, and our unpublished data). Thus, AIDS-KS cells produce factors which can induce proliferative events and histological changes similar to those found in human KS (9).

Several observations suggested that, among the cytokines produced by AIDS-KS cells $(8,9)$, basic fibroblast growth factor (bFGF), a well-characterized angiogenic factor $(11,13)$, is a major contributor to the development of $\mathrm{KS}$ lesions. In vitro, AIDS-KS cells derived from different patients all express high steady-state levels of bFGF mRNA (8), and contain abundant amounts of all bFGF protein isoforms (18, 23, and 25 $\mathrm{kD}$ ) in their nuclei and cytoplasm (8). Moreover, they release biologically active bFGF into the extracellular media in the absence of cell death (8). ${ }^{2}$ This extracellular bFGF induces both the growth of AIDS-KS cells themselves and normal endothelial cells (8). bFGF is also a predominant cytokine expressed in vivo in spindle cells of human $\mathrm{KS}$ lesions and detected at both mRNA $(14,15)$ and protein level (15a). In addition, inoculation of bFGF alone into nude mice induces the formation of vascular lesions closely resembling early KS in humans as well as the lesions induced by inoculation of AIDS-KS cells, with the exception that inflammatory cell infiltration and edema are more evident when KS cells are inoculated (15a) since they also produce inflammatory cytokines $(8,9)$.

To determine the role of bFGF in KS development and to

2. Samaniego, F., et al., manuscript submitted for publication. 
evaluate potential drug candidates for KS therapy, phosphorothioate-modified antisense (AS) oligodeoxynucleotides (24mers) complementary to bFGF mRNA were tested for their ability to block AIDS-KS cell growth in vitro and also inhibit angiogenesis in vitro and in the KS nude mice model. The results demonstrate that ASbFGF oligomers block AIDS-KS cell growth in vitro and inhibit the formation of angiogenic, KS-like, lesions induced by inoculation of AIDS-KS cells in nude mice. These effects are specific, obtained at low, nontoxic concentration, and are due to the inhibition of the production of bFGF which is required by AIDS-KS cells to enter the cell cycle and to promote endothelial cell growth and invasion.

\section{Methods}

Cell cultures. AIDS-KS3, -KS4, and -KS6 cell cultures were established from KS lesions of AIDS patients and cultured as previously described (6-8). Human umbilical vein-derived endothelial (H-UVE) cells were established and cultured in the presence of endothelial cell growth factor (ECGF) supplement ( $30 \mu \mathrm{g} / \mathrm{ml}$ ) (Collaborative Research Inc., Bedford, MA) or acidic FGF (aFGF) ( $10 \mathrm{ng} / \mathrm{ml}$ ) (R \& D Systems, Minneapolis, MN, or Boehringer Mannheim Biochemicals, Indianapolis, IN) and heparin $(45 \mu \mathrm{g} / \mathrm{ml})$ (Sigma Chemical Co., St. Louis, MO), as previously described $(6-8,16)$.

Oligodeoxynucleotides. ASbFGF and sense (S) bFGF phosphorothioate oligodeoxynucleotides (24-mers) were prepared on $1 \mu \mathrm{mol}$ or 10 $\mu$ mol scales with an Applied Biosystems Model 380B DNA synthesizer (Foster City, CA) using previously reported procedures (17). These include substitution of 0,0-diisopropyl-phosphorodithioic acid disulfide for iodine-water-pyridine and reversing the normal oxidation-then-cap sequence within each cycle, as described in U.S. patent No. 5, 292, 875; preparative reversed-phase high-performance liquid chromatography, detritylation, isolation of the final product in the form of its sodium salt, and analysis by capillary gel electrophoresis (18), which generally indicated $\geq 85 \%$ full-length product by comparison to size standards. Unmodified phosphodiester oligomers were obtained by use of iodinewater-pyridine for the oxidation step. The sequence of the AS oligomers synthesized is as follows. AS complementary to the translation start site (AUG codon) of bFGF mRNA: 5' GATGCTCCCGGCTGCCATGGTCCC 3'; Splice donor-acceptor site 1 (codon 60): 5' TTGTAGCTTGATGTGAGGGTCGCT $3^{\prime}$; Splice donor-acceptor site 2 (codon 9495): 5' ATCCGTAACACATTTAGAAGCCAG 3'. Corresponding sense phosphorothioate oligomers having reverse complementary sequences were synthesized as controls. A random oligonucleotide phosphorothioate (24-mer), used to monitor the extent of sequence nonspecific inhibition, was synthesized as a degenerate oligonucleotide by coupling a mixture of four nucleotides at each stage (theoretically it contains $4^{28}=7.2 \times 10^{16}$ sequences). This oligomer was kindly provided by J. Lisziewicz (LTCB, NCI). All oligomers were resuspended in sterile and endotoxin-free water at a concentration of $1 \mathrm{mM}$. Further dilutions were made in cell growth media.

Cell growth assays. AIDS-KS cell growth was evaluated by both $\left[{ }^{3} \mathrm{H}\right]$ thymidine incorporation assay and by the cell counting method. For the thymidine incorporation assay, cells were seeded in 96-well plates (Costar Corp., Cambridge, MA) at $0.8-1 \times 10^{3}$ cells $/$ well and the day after the oligomers or the medium in which the oligomers were diluted and $1 \mu \mathrm{Ci}$ of $\left[{ }^{3} \mathrm{H}\right]$ thymidine $(6.7 \mathrm{Ci} / \mathrm{mmol}$; NEN Research Products, Boston, MA) were added to each well (five replicates per sample) in medium containing $10 \%$ fetal bovine serum (FBS) (GIBCO BRL, Grand Island, NY) and in the absence of any cell growth supplement $(3-5)$, as previously described $(16,19,20) .24,48,72$, or $96 \mathrm{~h}$ later, cells were harvested and the cpm of incorporated thymidine were determined with $\beta$-Counter ( 1250 Beta Plate; LKB/Pharmacia, Piscataway, $\mathrm{NJ}$ ). The results were expressed as percent of cell growth compared with values in the absence of the oligomers (percent of control).

For the cell counting method, AIDS-KS cells were seeded in 12- well plates (Costar) at $3 \times 10^{3}$ cells/well (in duplicates) and cell number was determined $4 \mathrm{~d}$ after the addition of the oligomers or medium alone by Trypan blue dye exclusion, as previously described ( 8 , 19, 20).

For H-UVE cells, cell growth was evaluated by $\left[{ }^{3} \mathrm{H}\right]$ thymidine incorporation $48 \mathrm{~h}$ after the addition of the oligomers or controls to complete media (containing 10\% FBS and ECGF or aFGF) (6-8), as described above and elsewhere $(16,19)$.

Cell cycle analysis. The distribution of the cells in the different phases of the cell cycle was determined by FACS analysis after labeling the nuclei with propidium iodide (Boehringer Mannheim Biochemicals ). Briefly, AIDS-KS cells were plated in T75 cm $\mathrm{cm}^{2}$ flasks $\left(1 \times 10^{5}\right.$ cells/flask). Cells were then collected, fixed in cold $70 \%$ ethanol for $30 \mathrm{~min}$ in ice, centrifuged, and resuspended in $500 \mu \mathrm{l}$ of the staining solution $(100 \mu \mathrm{g} / \mathrm{ml}$ propidium iodide, $0.1 \%$ Triton X-100 [Sigma Chemical Co.], $37 \mu \mathrm{g} / \mathrm{ml}$ EDTA [Digene, College Park, MD] in phosphate buffered saline [PBS]) and $500 \mu \mathrm{l}$ of RNase (200 U/ml; Sigma Chemical Co.). Nuclei were then analyzed by flow cytometry using the Cellfit software (Becton Dickinson, San Jose, CA). The results were expressed as percent of cells in S-phase.

Rescue of cell growth with recombinant bFGF protein. Rescue assays were performed by both the cell counting method and FACS analysis and expressed as cell number or as percent of the cells in Sphase, respectively, after the addition of bFGF (Boehringer Mannheim Biochemicals) to oligomers-treated cells. In both cases, $48 \mathrm{~h}$ after the addition of the oligomers, cells were washed twice with media containing $15 \%$ FBS and medium alone or bFGF $(50 \mathrm{ng} / \mathrm{ml})$ were added to the cells and the assays continued as described above.

bFGF staining of cytospin preparations. A double-indirect immunoperoxidase method with affinity-purified mouse monoclonal anti-bFGF antibodies (1:150 dilution) raised against purified bovine brain bFGF (Promega, Madison, WI), was used to stain cytospin preparations as described elsewhere (20). Slides were counterstained with Harris Hematoxylin. SK-HEP cell line, a known bFGF-producing cell line (8) and a T cell line (H9) or PBS were used as positive and negative controls, respectively. The percentage of positive cells in duplicate samples for each experiment and in three fields per slide was evaluated and expressed as the mean $( \pm S D)$ of both cytoplasmic and nuclear stained-positive cells.

bFGF staining of mouse tissues. Frozen tissue sections from the site of inoculation of mice injected with SbFGF or ASbFGF-treated AIDS$\mathrm{KS}$ cells were stained with rabbit polyclonal anti-bFGF antibodies (Santa Cruz Biotechnology Inc., Santa Cruz, CA) by the peroxidaseantiperoxidase method. To reduce background staining, slides were incubated with normal swine serum (1:5 dilution) (Dakopatts, Glostrup, Denmark) for $30 \mathrm{~min}$ at room temperature before the addition of the primary antibody. Slides were then incubated ( $30 \mathrm{~min}$, room temperature) with the primary antibody diluted to $1: 20$ or $1: 40$ in 1\% PBS-BSA. Swine anti-rabbit (1:100 dilution, Dakopatts) and then peroxidaseantiperoxidase (rabbit) (1:100 dilution; Dakopatts) were added to the slides for 30 min each at room temperature. After each incubation, slides were washed in PBS for $10 \mathrm{~min}$ with gentle shaking. The peroxidase reaction was then developed as described elsewhere $(20)$ and slides were counterstained with Mayer's hematoxylin solution (Sigma Chemical Co.) before evaluation.

Preparation of conditioned media (CM) from AIDS-KS cells. CM were prepared as described previously (6-8) from AIDS-KS4 or -KS3 cells cultured for $24 \mathrm{~h}$ with serum-free medium with or without $0.5 \mu \mathrm{M}$ of AS or SbFGF oligomers. These CM were diluted 1:2 (in H-UVE cell growth media without ECGF or aFGF/bFGF and heparin and containing $20 \%$ FBS) for the cell growth assays with H-UVE cells or used undiluted or diluted in serum-free medium for the H-UVE cell invasion assays (see below).

H-UVE cell invasion through Matrigel. H-UVE cells $\left(1.5 \times 10^{5}\right)$ were resuspended in $800 \mu \mathrm{l}$ of serum-free medium containing $0.1 \%$ BSA (Sigma Chemical Co.) and placed in the upper compartment of the Boyden chambers (NeuroProbe, Inc., Cabin John, MD). The CM or serum-free medium (negative control) were placed in the lower com- 


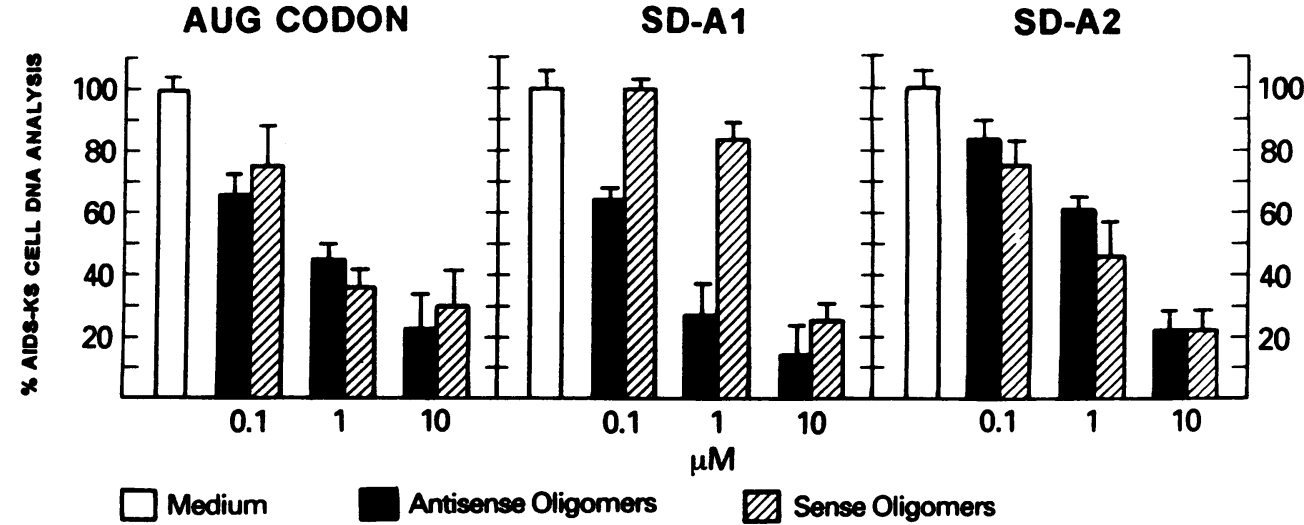

Figure 1. Effect of ASbFGF oligomers directed against different sequences of bFGF mRNA on AIDSKS cell growth. Percentage of AIDS-KS4 cell growth in the presence of medium alone $(\square)$, or in medium containing $0.1,1$, or 10 $\mu \mathrm{M}$ of AS ( $\mathbf{a})$, or $\mathrm{S}(\boldsymbol{\square})$ phosphorothioate oligomers directed against the translation start site (AUG codon), the SD-A site 1 (SD-A1), or SD-A site 2 (SD-A2) of bFGF mRNA. Cell growth was evaluated at $48 \mathrm{~h}$ by the $\left[{ }^{3} \mathrm{H}\right]-$ thymidine incorporation method and results were expressed as the percentage of cell growth compared to results in the absence of the oligomers (percent of control). partment. The two compartments of the Boyden chambers were separated by $12 \mu \mathrm{M}$ pore polycarbonate filters (Poretics Corp., Livermore, CA) coated with Matrigel (Collaborative Research) (diluted to a final concentration of $0.5 \mathrm{mg} / \mathrm{ml}$ ) which polimerizes at $37^{\circ} \mathrm{C}$ forming a basement membrane (21). The assay was performed as previously described (22). After $6 \mathrm{~h}$ of incubation at $37^{\circ} \mathrm{C}$ in a $5 \% \mathrm{CO}_{2}$ atmosphere, the cells on the upper surface of the filters were removed, and the filters were fixed in ethanol and stained by toluidine blue and hematoxylin/ eosin. Invaded cells present on the lower surface of the filter were quantitated "blindly" by light microscopy. The assays were carried out in duplicate and five fields/filter were counted.

Injection of AIDS-KS cells in nude mice. AIDS-KS3 or -KS4 cells were cultured for $48 \mathrm{~h}$ (at $50 \%$ confluence) in the presence or in the absence of $1 \mu \mathrm{M}$ of ASbFGF or SbFGF oligomers. Cells were then trypsinized, washed in PBS, and $3 \times 10^{6}$ cells were inoculated subcutaneously in the lower back of BALB/c nu/nu athymic mice, as previously described (7). Untreated cells cultured under the same conditions and medium only were used as controls. Mice were examined and sacrificed at $4 \mathrm{~d}$ after injection. At this time tissue samples were taken from the site of injection for both positive and negative animals. Specimens were either quick-frozen and cryosectioned for immunohistochemical staining or fixed in formalin. Tissue slides were analyzed microscopically after hematoxylin/eosin staining. Histological examination was performed on coded samples without prior knowledge of the macroscopic results. Histological changes such as angiogenesis, spindle cells proliferation, acute and chronic inflammatory cell infiltration and edema were scored using as negative controls the sites injected with medium alone in the absence of cells.

\section{Results}

Antisense bFGF phosphorothioate oligomers inhibit AIDS-KS cell growth specifically and in a dose-dependent fashion. Initial experiments were performed to determine the effect on AIDSKS cell growth of AS and corresponding $S$ oligomers, used as controls, directed against three different bFGF sequences: the translation start site (AUG codon) and splice donor-acceptor (SD-A) sites one and two of bFGF mRNA (23-25). The sequence of each of these oligomers is reported in Methods. The phosphorothioate modification was chosen because it renders the oligomers less susceptible to degradation (26). As shown in Fig. 1, inhibition of AIDS-KS cell growth was greatest and more specific with the AS oligomer directed against the SD-A site 1 of bFGF mRNA compared with the other AS oligomers tested. Computer analysis suggested that the more selective ef- fect of ASbFGF directed against the SD-A site 1 as compared with the other oligomers could be due to mRNA conformation. For example, the sequence targeted by the oligomer directed against the SD-A site 2 is presented as a loop while the sequence targeted by ASbFGF against the SD-A site 1 is exposed and likely accessible to the oligomer. Therefore, the SD-A site 1 oligomer, referred hereafter simply as ASbFGF, was chosen for further experiments.

As shown in Fig. $2 A$, ASbFGF inhibited the growth of AIDS-KS4 cells in a dose-dependent fashion with optimal effects at $0.5-1 \mu \mathrm{M}$. After $48 \mathrm{~h}$, these oligomer concentrations inhibited $53-73 \%$ of cell growth, respectively, while the corresponding S oligomer (SbFGF) had no effects. At concentrations of $2.5 \mu \mathrm{M}$ and greater, inhibition by ASbFGF was almost complete (85-97\%), however, at these concentrations, some inhibition was also observed with the $\mathrm{S}$ oligomer $(35-65 \%)$ (Fig. $2 A$ ).

To determine whether the phosphorothioate modification contributed to the inhibition of cell growth, ASbFGF and SbFGF unmodified phosphodiester oligomers were used for similar experiments. As shown in Fig. $2 B$, these oligomers had effects very similar to those with phosphorothioates, suggesting that the chemical modification does not contribute to cell growth inhibition. To verify the extent of non-sequence-specific inhibition by the ASbFGF oligomer, a phosphorothioate random oligomer of the same length was utilized as control. As shown in Fig. $2 C$, the random oligomer had very limited effect, indicating that most of the inhibition by ASbFGF is sequence specific. These results indicated that ASbFGF blocks KS cells growth specifically, at low and nontoxic concentration, and in a dosedependent fashion.

The inhibition of AIDS-KS cell growth by ASbFGF is timedependent, is rescued by exogenous bFGF and is associated with reduction of intracellular bFGF content. To determine the kinetic of AIDS-KS cell growth inhibition by ASbFGF, AS or SbFGF oligomers $(0.5$ and $1 \mu \mathrm{M})$ were added to the cells and growth was monitored at serial time points by the thymidine incorporation method. The levels of inhibition of cell proliferation by ASbFGF increased with time and lasted for more than $96 \mathrm{~h}$ after a single addition of the oligomer. As shown in Fig. $3 \mathrm{~A}$, by $96 \mathrm{~h}$, the addition of 0.5 and $1 \mu \mathrm{M}$ of the ASbFGF oligomer resulted in 68 and $86 \%$ cell growth inhibition, respec- 

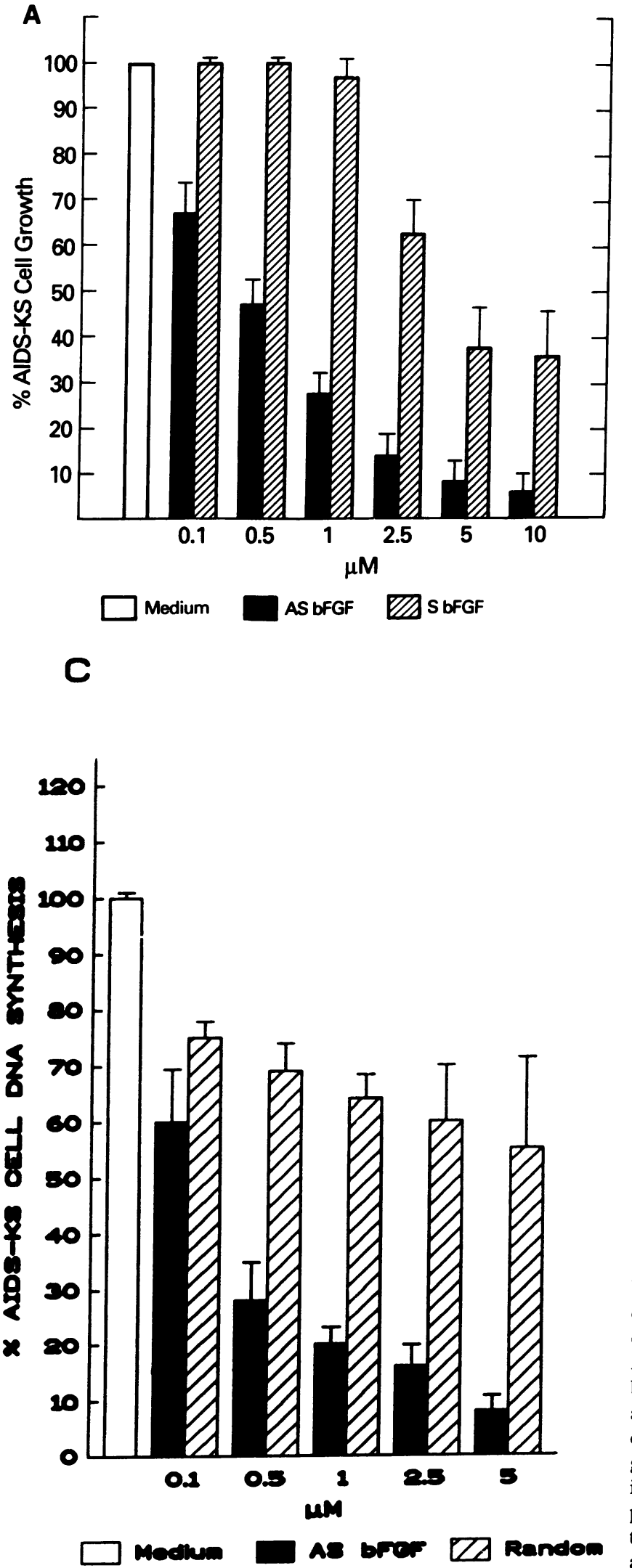

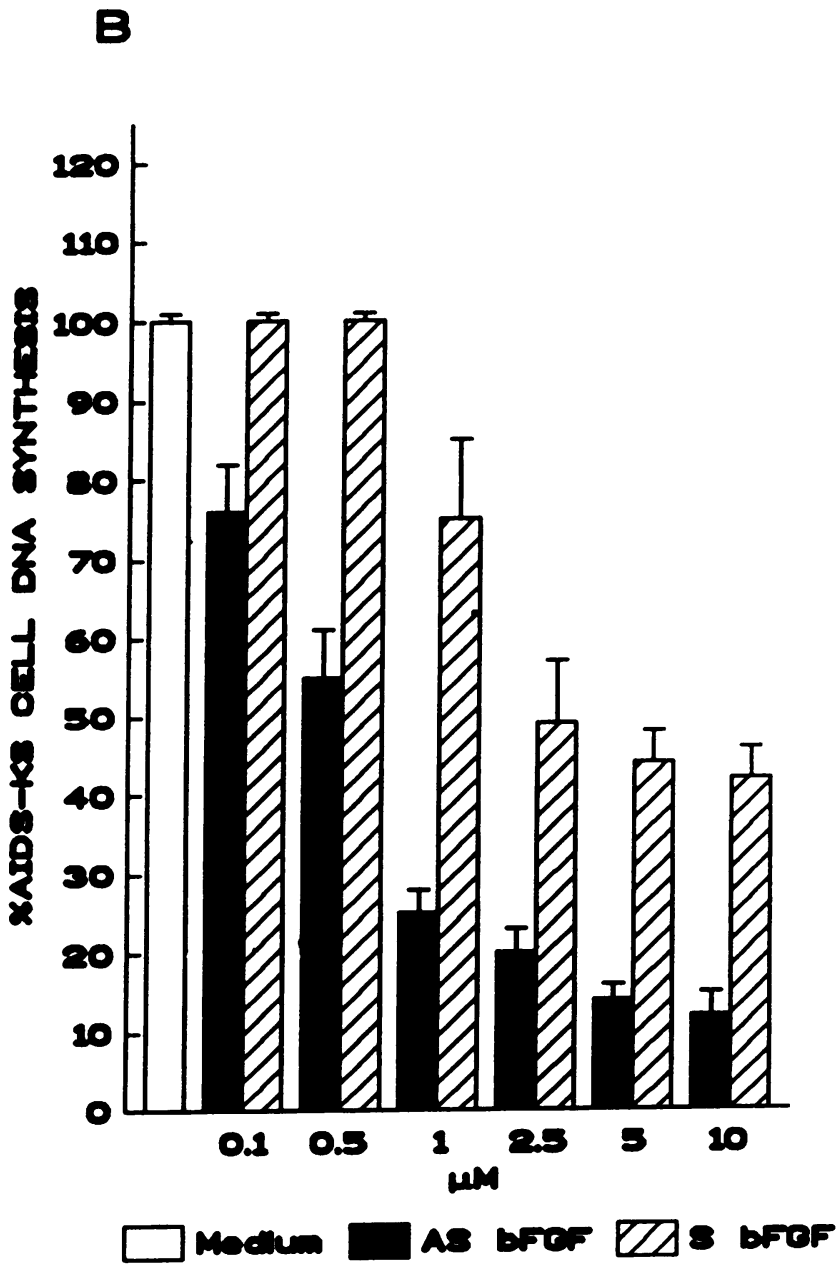

Figure 2. (A) Dose-dependent inhibition of AIDS-KS cell growth by AS oligomer directed against the first SD-A site of bFGF mRNA. Percentage of AIDS-KS4 cell growth in the presence of medium alone ( $\square$ ), or in medium containing increasing concentrations $(0.1-10 \mu \mathrm{M})$ of ASbFGF $(\square)$, or SbFGF ( $\square$ ) phosphorothioate oligomers directed against the SDA site 1 of bFGF mRNA. Cell growth was evaluated at $48 \mathrm{~h}$ by the $\left[{ }^{3} \mathrm{H}\right]$ thymidine incorporation method and results were expressed as described in the legend to Fig. 1. Similar or identical cell growth inhibitory effects were obtained with six different preparations of the same phosphorothioate oligomers. $(B)$ Unmodified phosphodiester ASbFGF oligomers block AIDS-KS cell growth at levels similar to phosphorothioates. Percentage of AIDS-KS4 cell growth in the presence of medium alone ( $\square$ ), or in the medium containing increasing concentrations $(0.1-10 \mu \mathrm{M})$ of AS ( $\square$ ) or S ( $\square$ ) phosphodiester oligomers directed against SD-A 1 of bFGF mRNA. Cell growth was evaluated at $48 \mathrm{~h}$ and results expressed as described in the legend to Fig. 1. $(C)$ The inhibitory effect of ASbFGF on KS cell growth is sequence specific. Percentage of AIDS-KS4 cell growth in the presence of medium alone ( $\square$ ) or in medium containing increasing concentrations (0.1-5 $\mu \mathrm{M})$ of ASbFGF ( $\square)$, or a random phosphorothioate oligomer $(\square)$. The random oligomer was used to monitor the extent of sequence-nonspecific inhibition. Cell growth was evaluated at $48 \mathrm{~h}$ and results expressed as described in the legend to Fig. 1. 

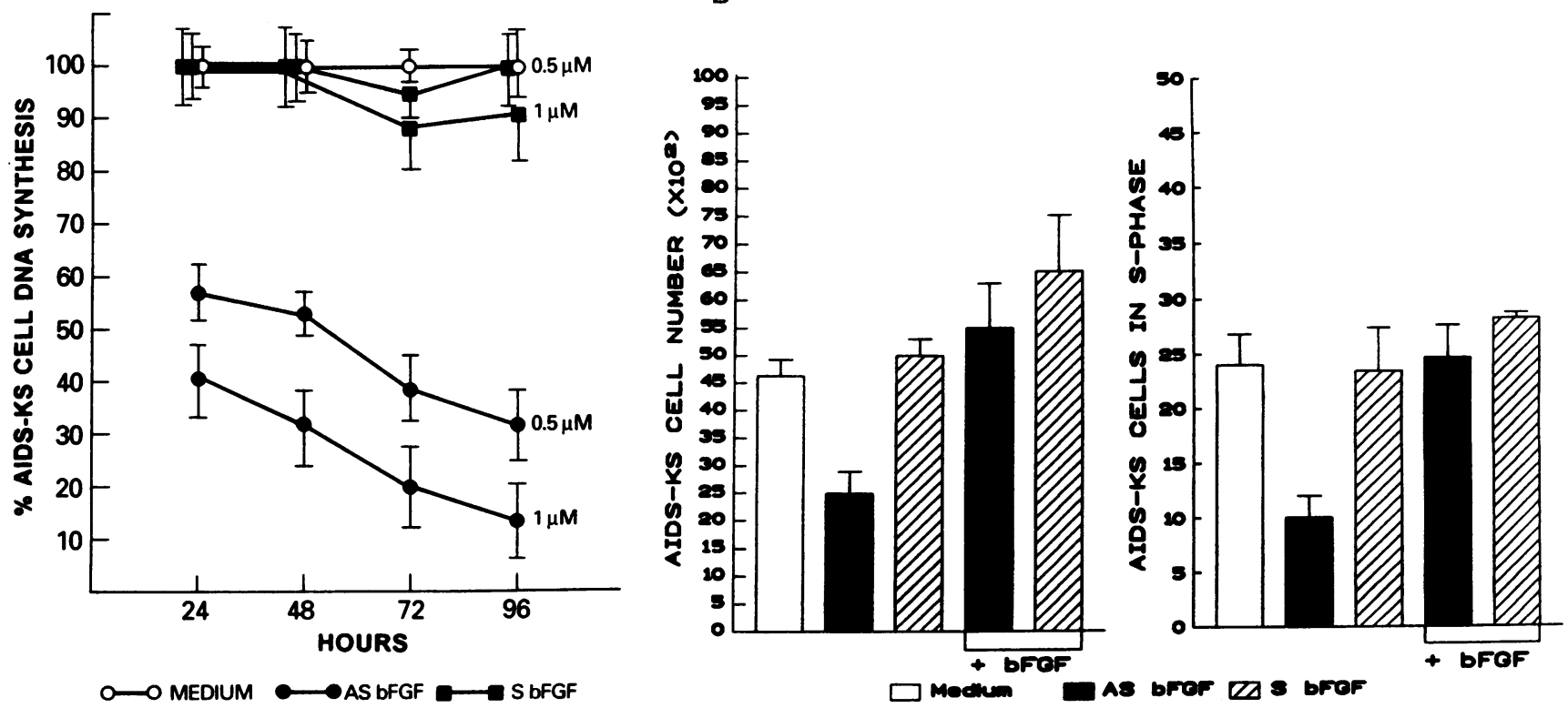

Figure 3. Cell growth inhibitory effect of ASbFGF over time after a single addition to AIDS-KS cells. Percentage of AIDS-KS4 cell growth at 24, 48,72 , and $96 \mathrm{~h}$ after the addition to the cells of medium alone $(\bigcirc-\bigcirc)$, or medium containing 0.5 or $1 \mu \mathrm{M}$ of ASbFGF $(\bullet-\bullet)$, or SbFGF $(\square-\square)$ oligomers. Cell growth was evaluated by $\left[{ }^{3} \mathrm{H}\right]$ thymidine incorporation method. $(B)$ ASbFGF oligomer blocks AIDS-KS cell growth by reducing the number of cells entering the S-phase of the cell cycle. This effect is reversed by the addition of recombinant bFGF protein to the cells. The percentage of AIDS-KS4 cells in S-phase (right panel) and cell number (left panel) were determined $4 \mathrm{~d}$ after the addition of $0.5 \mu \mathrm{M}$ of ASbFGF $(\varpi), 0.5 \mu \mathrm{M}$ of SbFGF $(\square)$, or medium alone $(\square) .48 \mathrm{~h}$ after the addition of the oligomers, cells were washed twice with media containing $15 \%$ FCS and medium alone or bFGF $(50 \mathrm{ng} / \mathrm{ml})$ were added to the cells. The results are the average of duplicate samples from three experiments. In the presence of ASbFGF, AIDS-KS cell number and the percentage of cells in S-phase were reduced to $49-54 \%$ and $42 \%$, respectively, as compared with S-treated or untreated cells. Cell death was undetectable. In both cases cell growth inhibition was reversed by the addition of bFGF. $(C)$ ASbFGF oligomer inhibits bFGF protein expression by AIDS-KS cells. From the upper to the lower panels: AIDS-KS4 cells cultured for $24 \mathrm{~h}$ in medium alone, with ASbFGF or with SbFGF oligomers $(0.5 \mu \mathrm{M})$. The numbers to the right are the percent bFGF-positive AIDS-KS cells $( \pm S D)$. The values in parenthesis represent the relative intensity of the cytoplasmic staining with + indicating minimal detectable signal. In AS-treated AIDS-KS cells nuclear bFGF staining was reduced from $36 \%( \pm 9)$ to $3 \%( \pm 1)$ positive cells. SK-HEP1 cell line, a known bFGF producing cell line (8), was used as a positive control ( $84 \% \pm 5$ bFGF positive cells), while a T cell line (H9) was used as a negative control $(0 \%)$. The average results of three fields per slide $(100$ cells/field $)$ are reported. The results were reproduced in two different experiments.

tively, while the $\mathrm{S}$ oligomer had no significant effects $(0-10 \%$ inhibition).

To verify that inhibition of DNA synthesis corresponded to an actual decline in the number of proliferating cells, both the cell number and the percentage of cells in S-phase were examined by Trypan blue dye exclusion and FACS analysis $96 \mathrm{~h}$ after the addition of $0.5 \mu \mathrm{M}$ of ASbFGF or SbFGF and compared to untreated cells. As shown in Fig. $3 B$, in the presence of ASbFGF, the percentage of cells in S-phase was reduced to $42 \%$ and the number of KS cells was reduced to $49-54 \%$ of the levels found with cells treated with the $S$ oligomer or with untreated cells. No cell death was detected. This inhibition was reversed by the addition of recombinant bFGF protein to AStreated cells, i.e., cell growth increased (both cell number and the percentage of cells in S-phase) reaching the same levels detected in the absence of the AS oligomer (Fig. $3 B$ ).

To confirm that ASbFGF reduced bFGF protein production, AIDS-KS cells were treated for $24 \mathrm{~h}$ with the ASbFGF or SbFGF oligomers $(0.5 \mu \mathrm{M})$ or with medium alone and then were stained by double-indirect immunoperoxidase with affinity purified anti-bFGF monoclonal antibodies. The number of bFGF positive cells and the intensity of both the cytoplasmic and nuclear bFGF staining were greatly reduced in ASbFGF- treated compared to SbFGF-treated or untreated cells (Fig. 3 $C$ ). This could be due to the degradation of bFGF mRNA by RNase $H$, as suggested in previous work with phosphorothioate oligomers $(23-26)$. These results indicated that ASbFGF blocks cell growth by reducing the number of cells entering the cell cycle. This is dependent on the presence of bFGF, and is associated with inhibition of the expression of bFGF in nuclei and cytoplasms (23-25).

ASbFGF oligomer blocks the growth of KS cells derived from different patients but not that of normal endothelial cells. The previous observations were extended to AIDS-KS cells derived from different patients (AIDS-KS3, -KS4, and KS6) (6-8). As shown in Fig. 4, $A$ and $B$, ASbFGF at $\leq 1$ $\mu \mathrm{M}$ specifically inhibited the growth of these cells but not that of H-UVE cells. Normal endothelial cells were chosen as control cells because they may represent the cell type of origin of AIDS-KS cells $(5,9)$ and because they normally produce little or no bFGF, but they proliferate in response to the cytokine (8).

$A S b F G F$ oligomer blocks the angiogenenic activity of $K S$ cells. AIDS-KS cells release biologically active bFGF into the cell culture supernatants $(8),{ }^{2}$ and CM from AIDS-KS cells induce endothelial cells to migrate, degrade, and cross the base- 

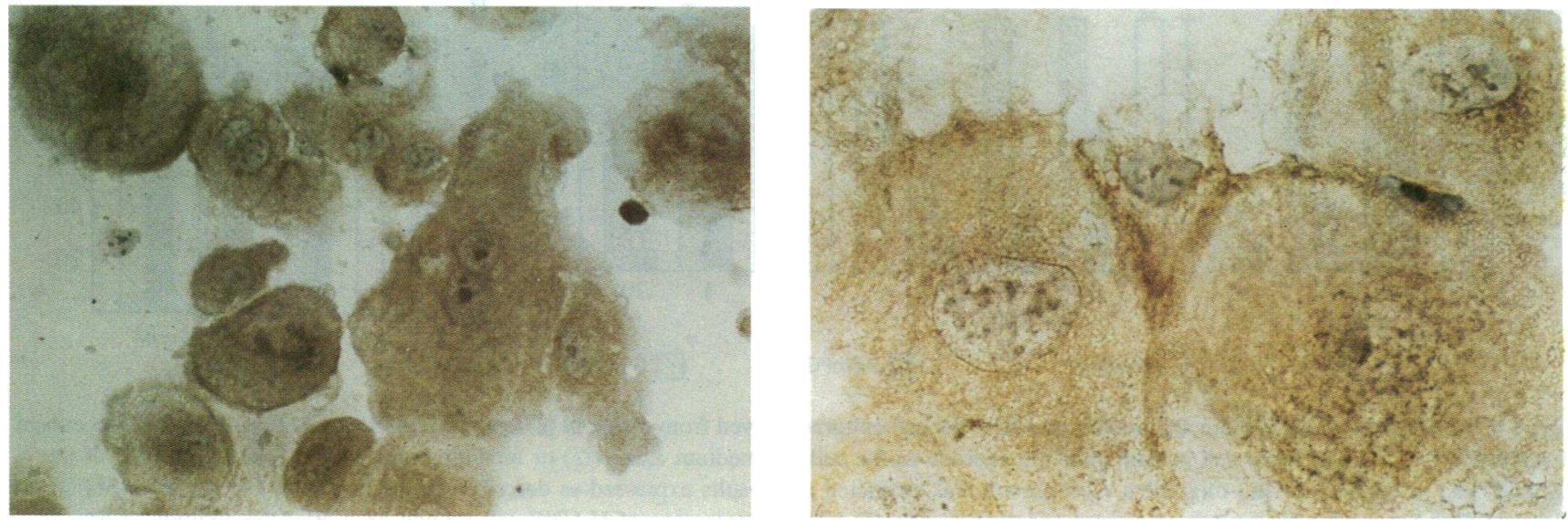

AS bFGF

$45 \% \pm 7(+)$
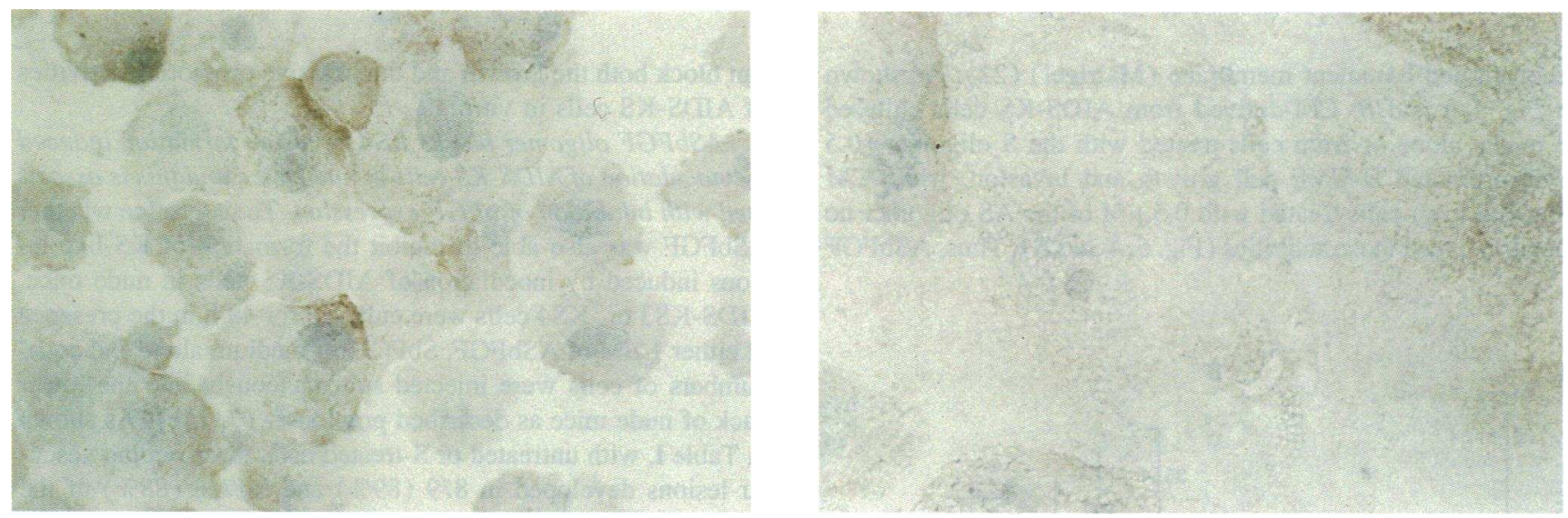

$S$ bFGF

$81 \% \pm 7(+++)$
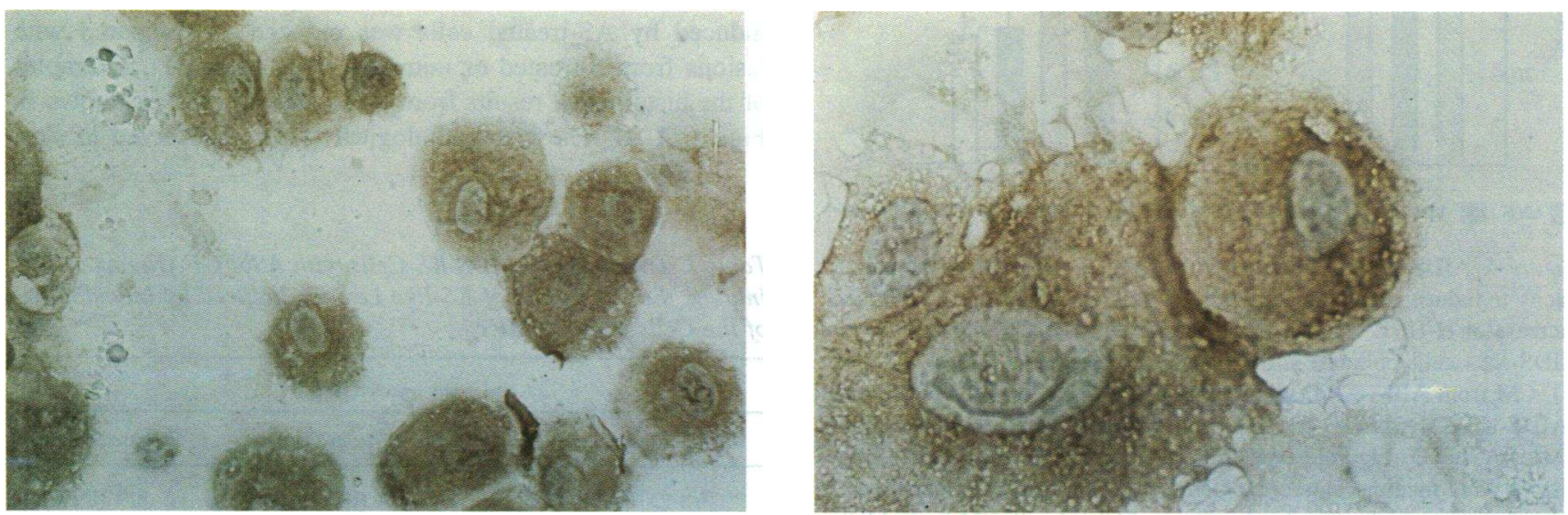

Figure 3 (Continued)

ment membrane (invasion) and to proliferate $(8,10)$ (Fig. 5, $A$ and $B$ ). These events, required for angiogenesis (11), are typical of KS $(1-5,9)$ and are also observed in nude mice after injection of AIDS-KS cells or bFGF (7)(15a). To verify that
bFGF mediates these activities of AIDS-KS cells, CM prepared from AIDS-KS cells treated for $24 \mathrm{~h}$ with either AS bFGF, S bFGF oligomers, or with medium alone were used to test the effect on H-UVE cell growth and cell invasiveness through a 
A ADS-KS3
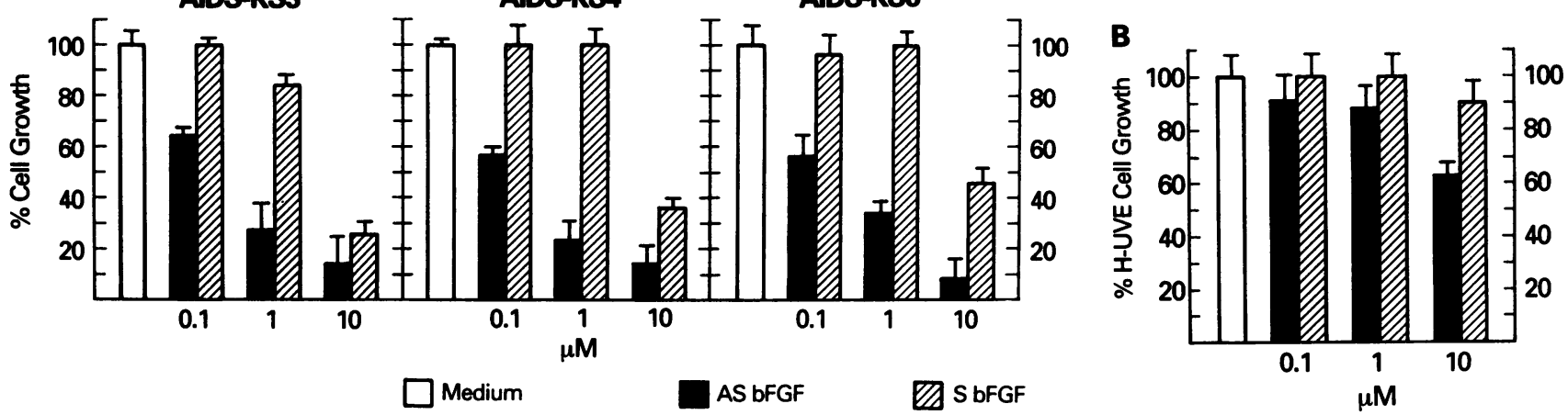

Figure 4. ASbFGF oligomer inhibits the growth of AIDS-KS cell cultures derived from different patients (AIDS-KS3, -KS4, and -KS6). Percentage of AIDS-KS3, -KS4, and -KS6 cell growth after the addition to the cells of medium alone ( $\square$ ) or medium containing $0.1,1$, and $10 \mu \mathrm{M}$ of the ASbFGF ( $\square$ ) or the SbFGF ( $\square$ ) oligomers. Cell growth was evaluated and results expressed as described in the legend to Fig. 1. (B) ASbFGF oligomer does not inhibit the growth of normal endothelial cells (H-UVE). Percentage of H-UVE cell growth $48 \mathrm{~h}$ after the addition of growth medium ( $\square$ ) or growth medium containing $0.1,1$, and $10 \mu \mathrm{M}$ of the ASbFGF ( $\square$ ) or the SbFGF ( $\square$ ) oligomers. Cell growth was evaluated by $\left[{ }^{3} \mathrm{H}\right]$ thymidine incorporation method as described in Methods.

reconstituted basement membrane (Matrigel) (22). As shown in Fig. 5, $A$ and $B, C M$-derived from AIDS-KS cells cultured in media alone or from cells treated with the $S$ oligomer $(0.5$ $\mu \mathrm{M}$ ) promoted H-UVE cell growth and invasion, while CM obtained from cells treated with $0.5 \mu \mathrm{M}$ of the AS oligomer no longer induced these activities (Fig. 5, $A$ and $B$ ). Thus, ASbFGF
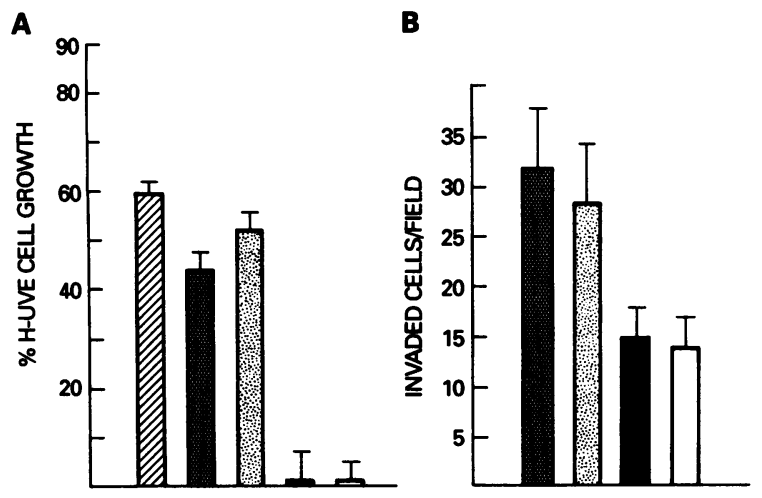

$\mathbb{Z b F G}$

ANDS-KS CM

ADS-KS CMS bFGF

AIDS-KS CMAS bFGF

Figure 5. AIDS-KS cells treated with ASbFGF oligomer loose the capacity to induce H-UVE cell growth $(A)$ and invasion $(B)$. ( $A$ ) Percent increase of $\mathrm{H}-\mathrm{UVE}$ cell growth in the presence of $\mathrm{CM}$ derived from AIDS-KS4 cells cultured in the absence of oligomers (AIDS-KS CM, (1), CM from AIDS-KS4 cells treated with $0.5 \mu \mathrm{M}$ of SbFGF oligomer (AIDS-KS CM/SbFGF, 1 ), CM from AIDS-KS4 cells treated with 0.5 $\mu \mathrm{M}$ of ASbFGF oligomer (AIDS-KS CM/ASbFGF, $\square$ ). bFGF ( $5 \mathrm{ng}$ / $\mathrm{ml})(\square)$ and medium alone ( $\square$ ) were used as positive and negative controls, respectively. Similar data were obtained with CM from AIDSKS3 cells. CM were prepared as described in Methods and cell growth was evaluated at $48 \mathrm{~h}$ by $\left[{ }^{3} \mathrm{H}\right]$ thymidine incorporation. $(B)$ Number of invaded $\mathrm{H}$-UVE cells per field in the presence of CM from AIDS-KS4 cells cultured in the absence of oligomers (AIDS-KS CM, ), CM from AIDS-KS 4 cells treated with $0.5 \mu \mathrm{M}$ of SbFGF (AIDS-KS CM/SbFGF, -), $\mathrm{CM}$ from AIDS-KS4 cells treated with $0.5 \mu \mathrm{M}$ of ASbFGF (AIDSKS CM/ASbFGF, $\square$ ). Medium alone was used as negative control ( $\square$ ). The assays were performed and evaluated as described in the Methods section. The values reported are the average of 10 fields. can block both the growth and the invasive promoting activities of AIDS-KS cells in vitro.

ASbFGF oligomer blocks KS-like lesion formation induced by inoculation of AIDS-KS cells in nude mice and this is associated with inhibition of bFGF expression. To determine whether ASbFGF was also able to inhibit the formation of KS-like lesions induced by inoculation of AIDS-KS cells in nude mice, AIDS-KS3 or -KS4 cells were cultured for $48 \mathrm{~h}$ in the presence of either $1 \mu \mathrm{M}$ of ASbFGF, SbFGF, or medium alone and equal numbers of cells were injected subcutaneously into the lower back of nude mice as described previously $(7,15 a)$. As shown in Table I, with untreated or S-treated cells macroscopic vascular lesions developed in $8 / 9(89 \%)$ and in $7 / 8(88 \%)$ of the mice inoculated, respectively. In contrast, with AS-treated cells, lesions developed in only $3 / 8(37 \%)$ of the animals $(P<0.005$ by chi square comparison of S-treated or untreated cells and AS-treated cells). In addition, the histopathology of the lesions induced by AS-treated cells was reduced as compared with lesions from S-treated or untreated cells (Table I). Examples of the histological results from these experiments are shown in Figs. $6, A-D$. The histopathological features observed in sites

Table I. Treatment of AIDS-KS Cells with ASbFGF Oligomer Inhibits the Formation of KS-like Lesions Induced by Inoculation of the Cells in Nude Mice

\begin{tabular}{ccc}
\hline \multicolumn{3}{c}{ Mice injected with } \\
\hline ASbFGF-treated cells & SbFGF-treated cells & Untreated cells \\
\hline $3 / 8(37 \%)^{*}$ & $7 / 8(88 \%)$ & $8 / 9(89 \%)$ \\
\hline
\end{tabular}

* Histopathology of these lesions was reduced up to $50 \%$ as compared with lesions from SbFGF-treated or untreated cells. Reported is the number of mice developing macroscopic vascular lesions closely resembling early KS versus the number of mice inoculated with AIDS-KS cells cultured for $48 \mathrm{~h}$ in the presence of ASbFGF $(1 \mu \mathrm{M})$, SbFGF $(1 \mu \mathrm{M})$ or medium alone. In parenthesis is reported the percentage of lesion-positive animals. $(P<0.005$ by chi square comparison of $S$ treated or untreated cells versus AS-treated cells). 
A
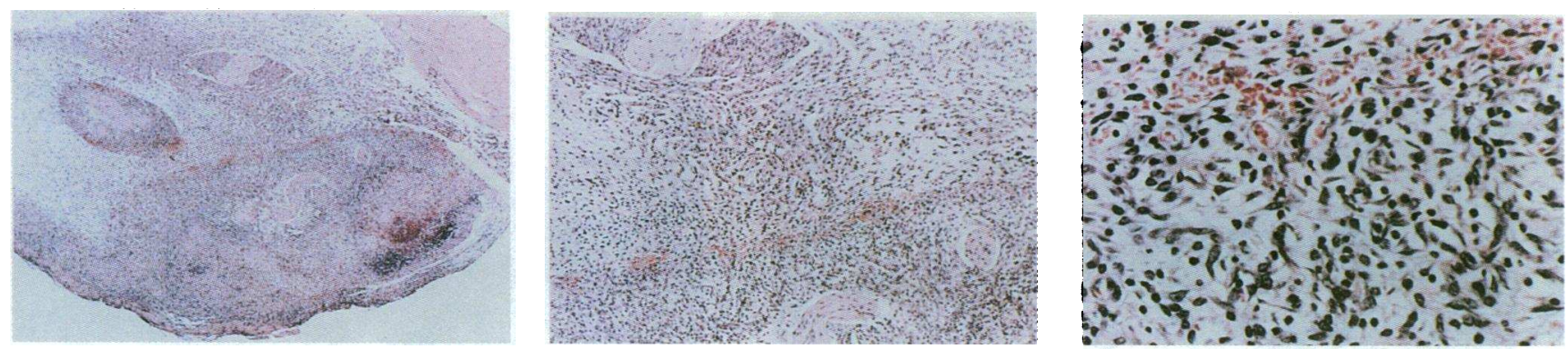

B
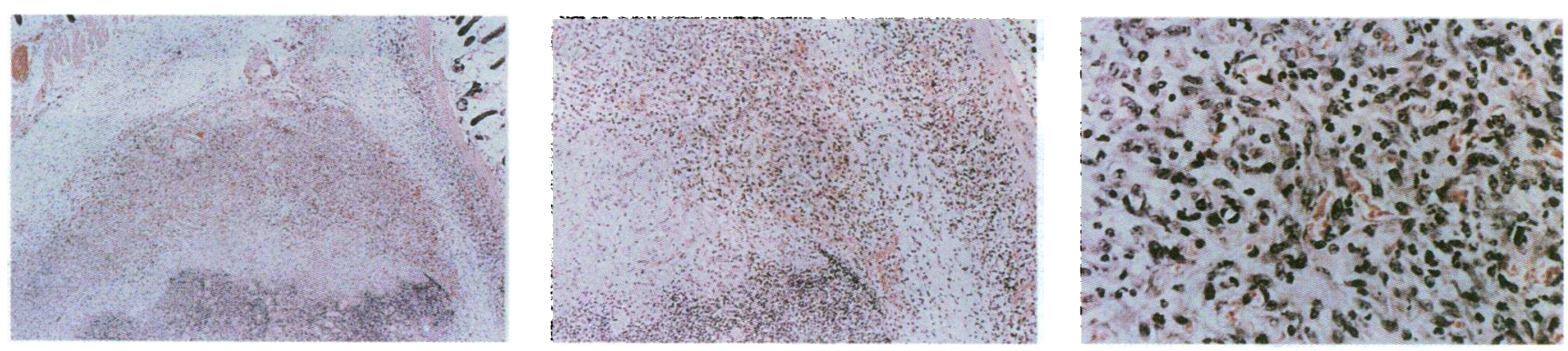

C
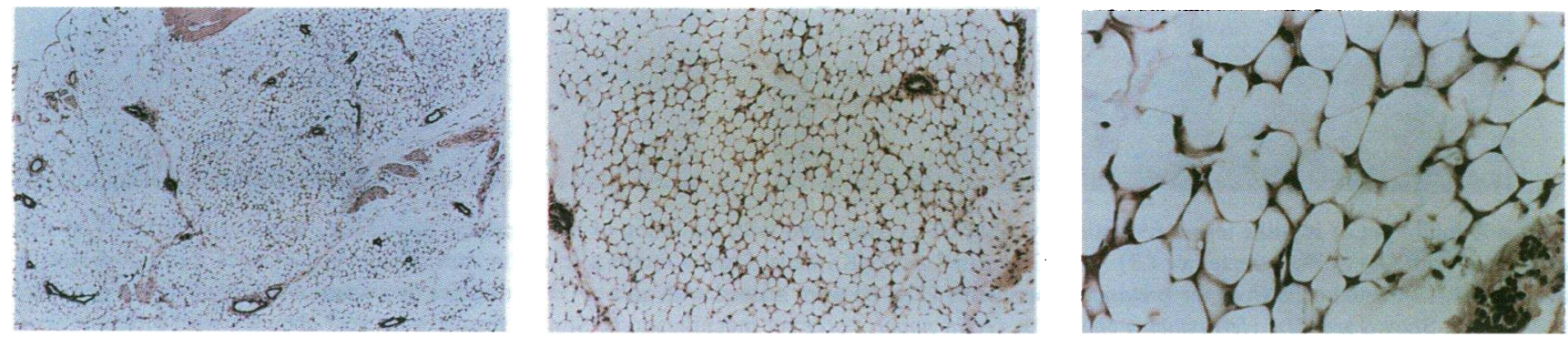

D
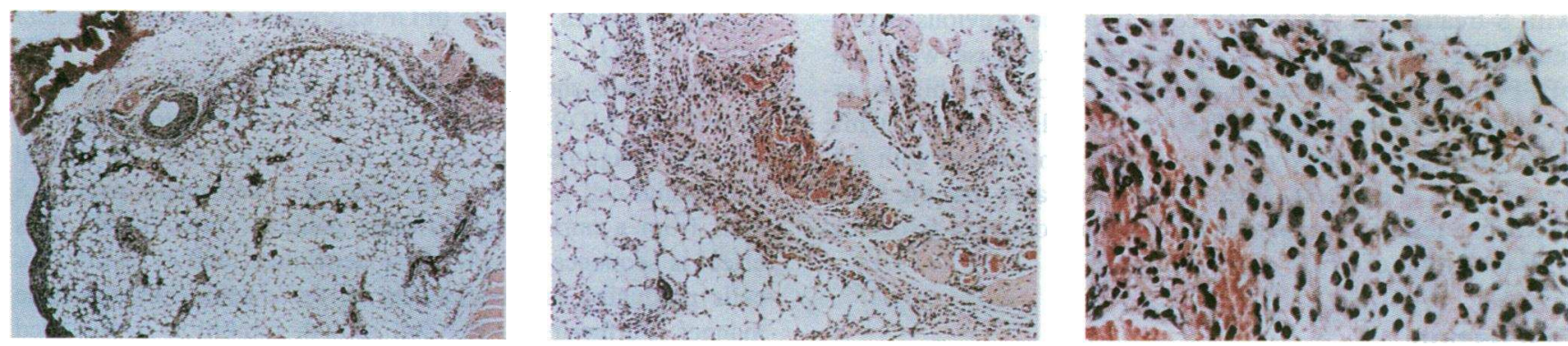

Figure 6. ASbFGF inhibits the formation of KS-like lesions induced by inoculation of AIDS-KS cells in nude mice. Shown are examples of the histopathology $(40 \times, 100 \times$, and $400 \times$ original magnifications from the left to the right panels, respectively) of the sites of injection from mice inoculated with either untreated AIDS-KS4 cells $(A)$, cells treated for $48 \mathrm{~h}$ with $1 \mu \mathrm{M}$ of SbFGF oligomer $(B)$, or cells treated for $48 \mathrm{~h}$ with 1 $\mu \mathrm{M}$ of ASbFGF oligomer which did not induce $(C)$, or induced $(D)$ a macroscopic vascular lesion. In this experiment, $3 / 3$ mice inoculated with untreated cells or S-treated cells, respectively, developed lesions characterized by the same histopathology (angiogenesis, spindle cells, inflammatory cell infiltration and edema) $(A$ and $B)$, while one-third animals inoculated with AS-treated cells developed a smaller lesion which was characterized by a reduced histopathology $(D)$.

inoculated with untreated AIDS-KS cells (Fig. 6 A) (angiogenesis, spindle cell growth, acute and chronic inflammatory cell infiltration and edema) were similar or identical to sites inoculated with S-treated cells (Fig. $6 \mathrm{~B}$ ), while they were absent
(Fig. $6 C$ ) or greatly reduced (Fig. $6 \mathrm{D}$ ) in sites inoculated with AS-treated cells.

To determine the level of bFGF expression in these tissues, frozen sections from the sites of injection of mice inoculated 
A
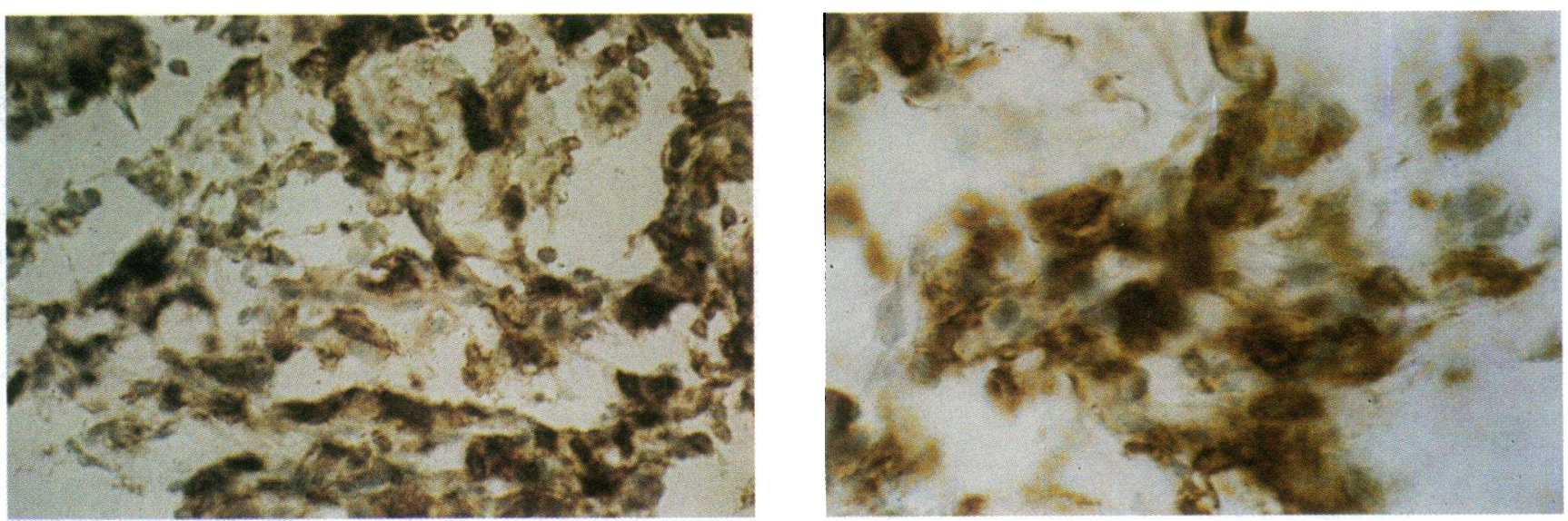

B
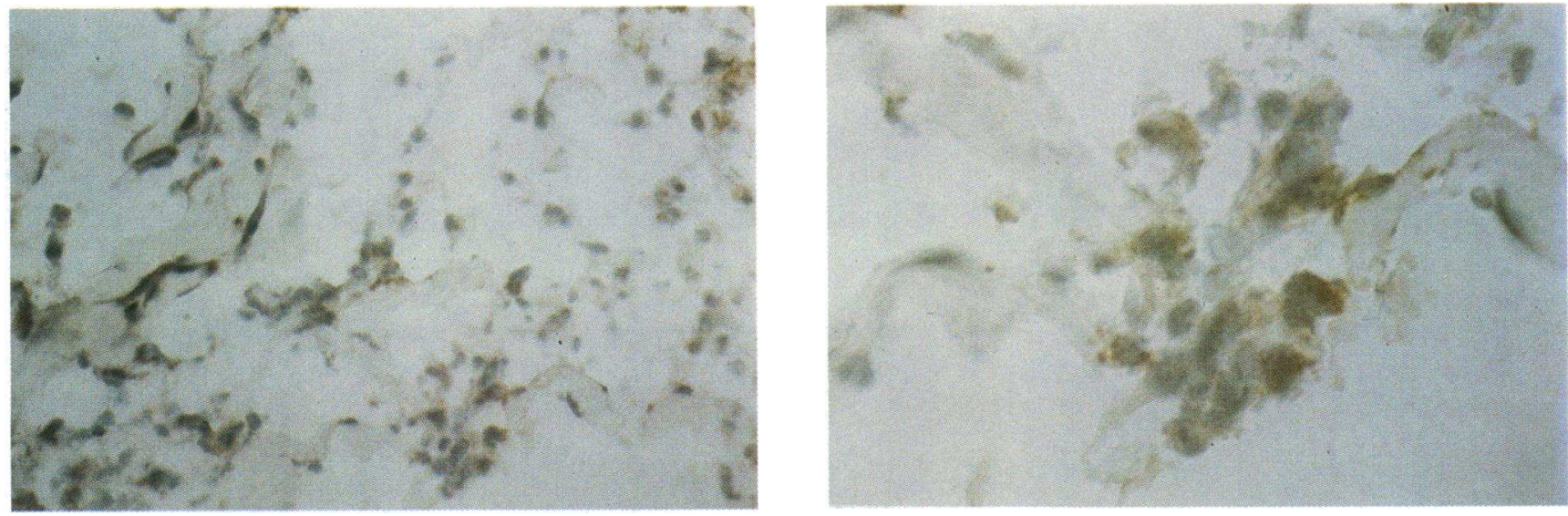

Figure 7. Inhibition of KS-like lesion formation by ASbFGF is associated with inhibition of bFGF protein expression. Expression of bFGF in sites inoculated with $(A)$ SbFGF-treated or $(B)$ ASbFGF-treated AIDS-KS cells. Frozen sections from the sites of injection of mice inoculated with Streated and AS-treated cells from the previous experiments (Fig. 6) were stained with anti-bFGF antibodies by immunohistochemistry as described in Methods. Shown are $40 \times$ (left panels) and $100 \times$ (right panels) original magnifications. Similar results were also obtained with different mice.

with S-treated and AS-treated cells from the previous experiment (Fig. 6) were stained by immunoperoxidase with antibFGF antibodies. As shown in Fig. 7, bFGF was highly expressed in mice inoculated with S-treated cells (Fig. $7 \mathrm{~A}$ ), while its expression was greatly reduced in mice inoculated with AStreated cells (Fig. $7 \mathrm{~B}$ ). These results indicated that the block of KS-like lesion formation by ASbFGF oligomers is associated with inhibition of bFGF expression in vivo.

\section{Discussion}

We and others have previously shown that bFGF is highly expressed in spindle cells of KS lesions both in vitro and in vivo $(8,14,15,15 a)$ and that $K S$ cells release this cytokine in the absence of cell death and in a biologically active form which mediates endothelial cell growth $(8) .{ }^{2}$ Recent data suggest that inflammatory cytokines (tumor necrosis factor, IL-1, and $\gamma$ IFN), which are elevated in individuals at high risk to develop KS (27), are responsible for the increased expression of bFGF in KS spindle cells. Specifically, these cytokines increase both the production and the release of biologically active bFGF from AIDS-KS cells and enhance the efficiency of these cells to induce KS-like lesions in the nude mice model. ${ }^{2}$ This is in agreement with previous data indicating that the same inflam- matory cytokines activate bFGF expression in normal vascular cells $(28,29)$.

The results shown herein indicate that bFGF is essential for growth of AIDS-KS cells. Block of bFGF production by ASbFGF oligomers led to the arrest of KS but not normal endothelial cell growth in the absence of cell death, using KS cells from a number of different patients (Figs. 1-4). This effect is sequence specific, dose dependent, and is specific for cells producing and responding to the cytokine in autocrine manner. Furthermore, KS cell growth inhibition is achieved with relatively low $(0.1-1 \mu \mathrm{M})$ concentrations of ASbFGF oligomers, and is reversed by the addition of exogenous bFGF (Figs. 2 and 3). After a single addition of ASbFGF oligomer at $0.5-1 \mu \mathrm{M}, \mathrm{KS}$ cell growth is progressively inhibited reaching values up to $68-86 \%$ inhibition by $96 \mathrm{~h}$ (Fig. $3 \mathrm{~A}$ ). Cell cycle analysis indicate that this progressive decline of cell growth is due to a reduction of the cells in S-phase and to their accumulation in G0-G1 (Fig. $3 \mathrm{~B}$ ). Thus, in the absence of bFGF AIDSKS cells cannot enter the S-phase of the cell cycle. However, this block is reversed by the addition of exogenous bFGF (Fig. $3 \mathrm{~B}$ ). The progressive decline of cell growth may also be due to the fact that the intracellular storage of bFGF must be depleted before full inhibitory effects by ASbFGF are evident. This is suggested by the reduced, but still detectable, bFGF 
content after treatment of $\mathrm{KS}$ cells with $0.5 \mu \mathrm{M}$ ASbFGF for 24 h (Fig. $3 C$ ).

AIDS-KS cells promote endothelial cell growth, migration, and invasion through Matrigel and when inoculated in nude mice they promote angiogenic lesions closely resembling early KS (Figs. 5 and 6; Table I) $(7,8,10)$. Injection in mice of recombinant bFGF alone induces similar effects (15a). We have previously shown that endothelial cell growth induced by $\mathrm{CM}$ from KS cells can be blocked by specific antibodies directed against bFGF (8). Here we demonstrate that after treatment with ASbFGF oligomers, AIDS-KS cells loose the capacity to induce endothelial cell growth, migration and invasion (Fig. $5, A$ and $B$ ), and to induce KS-like lesions in the nude mice model (Fig. 6; Table I). In particular, about $90 \%$ of the animals injected with untreated or S-treated AIDS-KS cells developed macroscopic vascular lesions, while with AS-treated AIDS-KS cells lesions developed only in $37 \%$ of the animals $(P<0.005)$. In addition, the lesions induced with ASbFGF-treated AIDS$\mathrm{KS}$ cells were characterized by a reduced histopathology (Fig. 6 ) and contained a much lower level of bFGF than lesion from S-treated mice (Fig. 7). Interestingly, in mice inoculated with AS-treated cells, the histopathology of the lesions was reduced in all its components, including inflammatory cell infiltration and edema (Fig. $6 \mathrm{D}$ ). This was somewhat unexpected since bFGF does not mediate inflammatory cell infiltration. However, since proliferating AIDS-KS cells, in addition to bFGF, also constitutively produce several inflammatory cytokines $(8,9$, 12), this may be an indirect effect due to a lower growth rate and, consequently, reduced cytokine production after ASbFGF treatment of the cells. Production of inflammatory cytokines by AIDS-KS cells may also contribute to the residual lesion formation observed with AS-treated cells. Specifically, inflammatory cytokines which are known to activate bFGF expression $(28,29)$, may induce endogenous (mouse) bFGF. Preliminary results suggest that this is the case. The injection at day 2 of AS or SbFGF oligomers complementary to the mouse sequence in the same sites inoculated with AS- or S-treated KS cells further reduced lesion formation.

The results of this study indicate that (a) bFGF is essential for growth of spindle cells derived from HIV-1-associated KS; (b) bFGF mediates the angiogenic activity of these KS spindle cells; and (c) bFGF is a key cytokine in the development of KS-like lesions in the nude mouse model. Since bFGF is expressed at high levels by spindle cells in human KS lesions (14, $15 \mathrm{a}$ ), this cytokine could be a good target for blocking KS development and progression, at least during the early stages of the disease. Furthermore, bFGF is present in KS lesions from both AIDS-associated and classical KS patients (14), suggesting that therapies specifically directed toward this molecule may be of benefit for all forms of KS. Drugs currently used or recently proposed for the treatment of KS include $\alpha$-IFN (3032 ), fumagillin (33) and a sulfated polysaccharide-peptidoglycan compound (SP-PG) (12). $\alpha$-IFN has been shown to block the progression of $\mathrm{KS}$ in $30-50 \%$ of the patients treated (3037 , particularly in the early phase of the disease, and recent evidence in other systems suggest that this is due to a block of bFGF activity (34). Fumagillin and SP-PG are currently in KS clinical trails. Both these drugs have been reported to inhibit angiogenesis and reduce the growth of tumors, including $\mathrm{KS}$, $(12,33)$ likely by blocking the activity of angiogenic factors, however, their exact mechanism of action and efficacy in KS are yet unknown.
Since several lines of evidence indicate that bFGF is a key molecule in the development of $\mathrm{KS}$ lesions, treatments that specifically target bFGF production, namely ASbFGF oligodeoxynucleotides, could replace or be combined with other drug to increase the therapeutic effect, as recently proposed by Folkman and Ingber (35) for combined use of fumagillin and $\alpha$-IFN in cancer therapy. The theoretical advantages of using ASbFGF oligomers in KS therapy include: $(a)$ high specificity of ASbFGF oligomers in inhibiting the expression of this molecule $(23-25) ;(b)$ the relative specificity for AIDS-KS cells; and (c) the in vitro and in vivo inhibition at low, presumably nontoxic, concentrations which may be achievable in vivo, as suggested by results with phosphorothioate oligomers directed to other targets $(36-39)$. It is well documented that angiogenesis is essential to tumor growth and even though it can be blocked by several drugs, compounds specifically blocking the production of angiogenic factors are lacking (35). Our data and results by others (23-26, 36-39) suggest that AS phosphorothioate and other types of oligonucleotide analogues against angiogenic factors may have broad applications in cancer therapy.

\section{Acknowledgments}

We thank L. DeDionisio, F. Raisishabary, L. Christensen, and A. Raible for the oligonucleotide preparations; Drs. H. S. Chang, F. Samaniego, and S. Colombini (LTCB, NCI) for critical review of the manuscript; L. Murty for reference searches; and L. Anderson for editorial assistance.

\section{References}

1. Friedman-Kien, A. E. 1981. Disseminated Kaposi's sarcoma syndrome in young homosexual men. J. Am. Acad. Dermatol. 5:468-471.

2. Safai, B., K. G. Johnson, P. L. Myskowski, S. Cunningham-Randles, J. H. Godbold, and B. Dupont. 1985. The natural history of Kaposi's sarcoma in the acquired immunodeficiency syndrome. Ann. Intern. Med. 103:744-750.

3. Haverkos, H. W., D. P. Drotman, and M. Morgan. 1985. Prevalence of Kaposi's sarcoma among patients with AIDS. N. Engl. J. Med. 312:1518.

4. Ruszczak, Z., A. Mayer-Da Silva, and C. E. Orfanos. 1987. Kaposi's sarcoma in AIDS. Am. J. Dermatopathol. 9:388-398.

5. Regezi, S. A., L. A. Macphail, T. E. Daniels, Y. G. De Souza, J. S. Greenspan, and D. Greenspan. 1993. Human immunodeficiency virus-associated oral Kaposi's sarcoma: a heterogeneous cell population dominated by spindleshaped endothelial cells. Am. J. Pathol. 143:240-249.

6. Nakamura, S., S. Z. Salahuddin, P. Biberfeld, B. Ensoli, P. D. Markham, F. Wong-Staal, and R. C. Gallo. 1988. Kaposi's sarcoma cells: long term culture with growth factor from retrovirus-infected $\mathrm{CD}^{+}{ }^{+} \mathrm{T}$ cells. Science (Wash. DC). 242:427-430.

7. Salahuddin, S. Z., S. Nakamura, P. Biberfeld, M. H. Kaplan, P. D. Markham, L. Larsson, and R. C. Gallo. 1988. Angiogenic properties of Kaposi's sarcomaderived cells after long-term culture in vitro. Science (Wash. DC). 242:430-433.

8. Ensoli, B., S. Nakamura, S. Z. Salahuddin, P. Biberfeld, L. Larsson, B. Beaver, F. Wong-Staal, and R. C. Gallo. 1989. AIDS Kaposi's sarcoma derived cells express cytokines with autocrine and paracrine growth effects. Science (Wash. DC). 243:223-226.

9. Ensoli, B., and R. C. Gallo. 1992. Growth factors in AIDS-associated Kaposi's sarcoma: cytokines and HIV-1 TAT protein. AIDS Updates. 5:1-7.

10. Thompson, E. W., S. Nakamura, T. H. Shima, A. Melchiorri, G. R. Martin, S. Z. Salahuddin, R. C. Gallo, and A. Albini. 1991. Supernatants of acquired immunodeficiency syndrome related Kaposi's sarcoma cells induce endothelial cell chemotaxis and invasiveness. Cancer Res. 51:2670-2676.

11. Folkman, J., and M. Klagsbrun. 1987. Angiogenic factors. Science (Wash. DC). 235:442-447.

12. Nakamura, S., S. Sakurada, S. Z. Salahuddin, Y. Osada, N. G. Tanaka, N. Sakamoto, M. Sekiguchi, and R. C. Gallo. 1992. Inhibition of development of Kaposi's sarcoma-related lesions by a bacterial cell wall complex. Science (Wash. DC). 255:1437-1440.

13. Burgess, W. H., and T. Maciag. 1989. The heparin binding (fibroblast) growth factor family of proteins. Annu. Rev. Biochem. 58:575-606.

14. Xerri, L., J. Hausson, J. Planche, V. Guigou, J. J. Grob, P. Parc, D. Birnbaum, and O. Delapeyriere. 1991. Fibroblast growth factor gene expression 
in AIDS-Kaposi's sarcoma detected by in situ hybridization. Am. J. Pathol. 138:915.

15. Li, J. J., Y. Q. Huang, D. Moscatelli, and A. E. Friedman-Kien. 1993. Expression of fibroblast growth factors and their receptors in acquired immunodeficiency syndrome-associated Kaposi's sarcoma tissue and derived cells. Cancer. 72:2253-2258.

15a. Ensoli, B., R. Gendelman, P. Markham, V. Fiorelli, S. Colombini, M. Raffeld, A. Cafaro, H.-K. Chang, J. N. Brady, and R. C. Gallo. 1994. In vitro and in vivo evidence that basic fibroblast growth factor and human immunodeficiency virus type-1 Tat protein synergize in inducing Kaposi's sarcoma development. Nature (Lond.). In press.

16. Barillari, G., L. Buonaguro, V. Fiorelli, J. Hoffman, F. Michaels, R. C. Gallo, and B. Ensoli. 1992. Effects of cytokines from activated immune cells on vascular cell growth and HIV-1 gene expression: implications for AIDS-Kaposi's sarcoma pathogenesis. J. Immunol. 149:3727-3734.

17. Zon, G., and W. J. Stec. 1991. Phosphorothioate oligonucleotides. In Oligonucleotides and Analogues: a Practical Approach. F. Eckstein, editors. Oxford University Press/Oxford, England. 87-108.

18. Zon, G., and T. Geiser. 1991. Phosphorothioate oligonucleotides: chemistry, purification, analysis, scale-up and future directions. Anti-Cancer Drug Des. 6:539-568.

19. Ensoli, B., G. Barillari, S. Z. Salahuddin, R. C. Gallo, and F. Wong-Staal. 1990. Tat protein of HIV-1 stimulates growth of cells derived from Kaposi's sarcoma lesions of AIDS patients. Nature (Lond.) 345:84-86.

20. Ensoli, B., L. Buonaguro, G. Barillari, V. Fiorelli, R. Gendelman, R. A. Morgan, P. Wingfeld, and R. C. Gallo. 1993. Release, uptake, and effects of extracellular human immunodeficiency virus type 1 Tat protein on cell growth and viral transactivation. J. Virol. 67:277-287.

21. Kubota, Y., N. Kleinman, G. R. Martin, and T. Lawley. 1988. Role of laminin and basement membrane in the morphological differentiation of human endothelial cells into capillary-like structures. J. Cell Biol. 107:1589-1598.

22. Albini, A., Y. Iwamoto, H. K. Kleinman, G. R. Martin, S. A. Aaronson, J. M. Kozlowski, and R. N. McEwan. 1987. A rapid in vitro assay for quantitating the invasive potential of tumor cells. Cancer Res. 47:3239-3245.

23. Becker, D., C. B. Meier, and M. Herlyn. 1989. Proliferation of human malignant melanomas is inhibited by antisense oligodeoxynucleotides targeted against basic fibroblast growth factor. EMBO (Eur. Mol. Biol. Organ.) J. 8:36853691

24. Morrison, R. S. 1991. Suppression of basic fibroblast growth factor expression by antisense oligodeoxynucleotides inhibits the growth of transformed human astrocytes. J. Biol. Chem. 266:728-734.

25. Murphy, P. R., Y. Sato, and R. S. Knee. 1992. Phosphorothioate antisense oligonucleotides against basic fibroblast growth factor inhibit anchorage-depen- dent and anchorage-independent growth of a malignant glioblastoma cell line. Mol. Endocrinol. 6:877-884.

26. Neckers, L., L. Whitesell, A. Rosolen, and D. A. Geselowits. 1992. Antisense inhibition of oncogene expression. Crit. Rev. Oncog. 3:175-231.

27. Fan, J., H. Z. Bass, and J. L. Fahey. 1993. Elevated IFN-gamma and decreased IL-2 gene expression are associated with HIV infection. J. Immunol. 151:5031-5037.

28. Gay, C. G., and J. A. Winkles. 1991. Interleukin-1 regulates heparinbinding growth factor 2 gene expression in vascular smooth muscle cells. Proc Natl. Acad. Sci. USA. 88:286-300.

29. Okamura, K., Y. Sato, T. Matsuda, R. Hananaka, M. Ono, K. Kohno and M. Kuwano. 1992. Endogenous basic fibroblast growth factor-dependent Induction of collagenase and interleukin- 6 in tumor necrosis factor-treated human microvascular endothelial cells. J. Biol. Chem. 266:19162-19165.

30. Krown, S. E. 1987. The role of interferon in the therapy of epidemic Kaposi's sarcoma. Semin. Oncol. 14:27-33.

31. Mitsuyasu, R. T. 1991. Interferon alpha in the treatment of AIDS-related Kaposi's sarcoma. Br. J. Haematol. 79:69-73.

32. Scjaart, F. M., B. Bratzke, Z. B. Ruszczak, R. Stadler, G. Ehlers, and C. E. Orfanos. 1991. Long term therapy of HIV-associated Kaposi's sarcoma with recombinant interferon alpha-2a. Br. J. Dermatol. 124:61-68.

33. Ingber, D. E., T. Fujita, S. Kishimoto, K. Sudo, T. Kanamaru, H. Brem, and J. Folkman. 1990. Synthetic analogues of fumagillin that inhibit angiogenesis and suppress tumor growth. Nature (Lond.). 348:555-557.

34. Fidler, I. J. 1993. Proceedings of the American Association of Cancer Research. Cancer Res. 34:570.

35. Folkman, J., and D. E. Ingber. 1992. Inhibition of angiogenesis. Semin. Cancer Biol. 3:89-96.

36. Simons, M., E. R. Edelman, J. L. Defeyser, R. Langer, and R. D. Rosenberg. 1992. Antisense c-myb oligonucleotides inhibit intimal arterial smooth muscle cell accumulation in vivo. Nature (Lond.). 359:67-70.

37. Ratajczak, M. Z., S. M. Uger, K. DaRiel, J. Abrahm, B. Calabretta, and A. M. Gewirtz. 1992. Role of the KIT protooncogene in normal and malignant human hematopoiesis. Proc. Natl. Acad. Sci. USA. 89:1710-1714.

38. Wahlestedt, C., E. Golanov, S. Yamamoto, F. Yee, H. Ericson, H. Yoo, C. E. Inturrisi, and D. J. Reis. 1993. Antisense oligodeoxynuclsotides to NMDA$\mathrm{R} 1$ receptor channel protect cortical neurons from excitotoxicity and reduce focal ischaemic infarctions. Nature (Lond.). 363:260-263.

39. Whitesell, L., D. Geselowitz, C. Chavany, B. Fahmy, S. Walbridge, J. Alger, and L. M. Neckers. 1993. Stability, clearance, and disposition of intraventricularly administered oligodeoxynucleotides: implications for therapeutic application within the central nervous system. Proc. Natl. Acad. Sci. USA. 90:46644669. 